\title{
PENINGKATAN KEMAMPUAN MENYIMAK BERITA DENGAN MENGGUNAKAN METODE TEAM PRODUCT
}

\author{
Nur Hafsah Yunus MS*
}

\begin{abstract}
This study aims to: (1) To find out the implementation of learning to listen to news using Team Product method on class VIII students SMP Negeri 3 Malunda; (2) To find out how the team product method can improve the ability to listen to the news of the students of class VIII SMP Negeri 3 Malunda. The population as the object of this research is class VIII SMPN 3 Malunda, Malunda Sub-district, Majene Tengah Regency for the academic year 2017 / 2018. The total number of students of class VIIID is 32 students, but the subject in this study only 30 students, sample in this study. Instruments used in this study there are two kinds of news capabilities and tests test questionnaire. The ability test is used to know the ability of the students to use the team product method to improve the ability to listen to the news, while the questionnaire used as data collection to determine the factors that influence the use of team product method to improve the ability to listen to news. The results of this study show the use of team product method to improve the ability of listening news is not sufficient, because the sample did not achieve results in accordance with predefined criteria. Factors affecting the ability of the students through the use of team product methods to improve the ability to listen to news are: Factors phsikologi learners, media limitations and facilities of instruction, environmental factors. From the results of the above analysis can be concluded that the level of use of team product methods in improving the ability to listen to news students in grade VIII SMPN 4 Malunda, Malunda District, Majene District has not been adequate.
\end{abstract}

Keywords : Team product method, listening to news, improving

\section{PENDAHULUAN}

Manusia membutuhkan bahasa untuk berkomunikasi agar tercipta interaksi dengan orang lain. Untuk itu, kemampuan mendengarkan amat

*) Prodi Pendidikan Bahasa Indonesia, Universitas Al Asyariah Mandar E-mail: nurhafsah@unasman.ac.id 
penting dimiliki setiap pemakai bahasa. Tarigan (2008: 1) menyatakan bahwa keterampilan berbahasa (atau language arts, language skills) dalam kurikulum di sekolah biasanya mencakup empat segi, yaitu menyimak (listening skills), berbicara (speaking skills), membaca (reading skills), dan menulis (writing skills).

Di antara keempat keterampilan tersebut, keterampilan menyimak merupakan keterampilan yang memungkinkan seorang pemakai bahasa memahami bahasa yang digunakan secara lisan. Tanpa kemampuan menyimak yang baik, sebuah komunikasi akan mengalami banyak kesalahpahaman di antara sesama pemakai bahasa, yang akhirnya dapat menimbulkan hambatan dalam melakukan kegiatan.

Menurut Tarigan (2008: 2), mula-mula pada masa kecil dipelajari keterampilan menyimak bahasa, kemudian berbicara, membaca dan akhirnya menulis. Keterampilan menyimak dan berbicara dipelajari sebelum memasuki sekolah, sedangkan keterampilan membaca dan menulis dipelajari di sekolah. Di sekolah, guru mata pelajaran Bahasa Indonesia dituntut profesional untuk dapat memotivasi peserta didik agar mempelajari dan menyenangi keempat keterampilan berbahasa tersebut. Peserta didik tidak hanya menguasai teoriteori tentang kebahasaan, tetapi ia harus mampu menerapkannya dalam berbagai peristiwa berbahasa atau dalam berkomunikasi.

Guru mata pelajaran Bahasa Indonesia sebagai fasilitator dalam menyampaikan segala ilmu pengetahuan dan informasi harus peka dengan segala masalah yang dialami setiap peserta didik. Salah satu permasalahan yang muncul adalah daya simak peserta didik yang rendah. Pada umumnya peserta didik yang secara akademik pandai, mempunyai daya simak yang tinggi. Begitu pula sebaliknya, peserta didik yang secara akademik kurang pandai, mempunyai daya simak yang rendah. Pada kenyataannya, latar belakang dan pengetahuan terhadap pembinaan kemahiran mendengarkan masih belum memadai. Hal ini dikarenakan referensi pengajaran menyimak masih kurang. Selain itu, media dalam pembelajaran menyimak juga masih terbatas.

Berdasarkan hasil pengamatan peneliti pada saat melaksanakan kegiatan PPL pada bulan Agustus sampai Desember tahun 2015, dapat dikatakan bahwa kemampuan menyimak peserta didik SMP Negeri 3 Malunda belum seperti yang diharapkan. Hal ini dapat ditunjukkan pada daya simak dan konsentrasi peserta didik dalam menyimak laporan perjalanan teman yang masih tergolong rendah dengan nilai rata-rata kelas 50 dari skor maksimal 100 pada peserta didik kelas VIIIA tahun ajaran 2015/2016.

Peserta didik tidak menyimak laporan perjalanan yang dibacakan atau disampaikan oleh peserta didik lainnya. Mereka lebih memilih untuk mengobrol, 
sehingga mengganggu konsentrasi peserta didik yang lain. Dari hasil pengamatan tersebut, diperkirakan kemampuan menyimak peserta didik kelas VIII lebih rendah dari peserta didik kelas VIIII. Hal tersebut dibuktikan melalui data nilai peserta didik kompetensi dasar menyimak berita pada peserta didik kelas VIII tahun ajaran 2017/2018, dengan nilai rata-rata kelas 5 dari skor maksimal 15 pada peserta didik kelas VIII. Begitu pula pada tahun ajaran 2016/2017, nilai rata-rata menyimak berita peserta didik tergolong rendah yakni di bawah skor 10 dari skor maksimal 15 pada peserta didik kelas VIII.

Banyak kesulitan yang dihadapi peserta didik dalam pembelajaran menyimak berita yang dibacakan. Kesulitan tersebut antara lain yakni suara model yang terlalu pelan dalam membacakan teks berita, pembacaan teks berita yang terlalu cepat dan kurang memperhatikan aspek nonkebahasaan, seperti tekanan, nada, intonasi, ritme, dan jangka suara. Selain itu, kesulitan lain yang dihadapi peserta didik yakni berupa gangguan dari teman satu kelas, seperti mengajak berbicara atau suara berisik dari teman yang sedang mengobrol, dan gangguan dari luar kelas seperti adanya pengumuman dari pihak sekolah yang akhirnya mengganggu konsentrasi peserta didik dalam menyimak.

Selain itu, dari hasil wawancara yang telah peneliti lakukan kepada guru pengampu mata pelajaran Bahasa Indonesia pada tanggal 05 Oktober 2017, diketahui terdapat beberapa permasalahan yang dihadapi terkait dengan rendahnya kemampuan peserta didik dalam menyimak berita. Permasalahan tersebut antara lain yakni, kurangnya jumlah buku ajar dalam pembelajaran menyimak berita dan perhatian guru dalam pemberian tugas. Hal ini mempengaruhi kurangnya pemahaman peserta didik terhadap materi pelajaran menyimak berita khususnya mengenai isi/sari berita. Selain itu, pada saat kegiatan pembelajaran berlangsung peserta didik kurang konsentrasi karena kurangnya penggunaan metode yang menarik dan pemanfaatan media yang sebenarnya telah disediakan pihak sekolah. Beberapa permasalahan di atas merupakan alasan yang mendorong peneliti untuk melakukan penelitian.

\section{Menyimak}

Menyimak merupakan salah satu keterampilan berbahasa dari empat keterampilan yang harus dikuasai peserta didik. Menyimak memiliki makna mendengarkan atau memperhatikan baik-baik apa yang diucapkan orang lain. Menyimak adalah kegiatan yang sengaja dilakukan, memiliki target tingkat pemahaman yang dibutuhkan serta memperhatikan aspek-aspek nonkebahasaan, seperti tekanan, nada, intonasi, ritme, dan jangka suara. Dengan demikian, menyimak merupakan kegiatan mendengarkan bunyi bahasa secara sungguh-sungguh, seksama, sebagai upaya memahami ujaran 
sebagaimana yang dimaksudkan pembicara dengan melibatkan seluruh aspek mental kejiwaan seperti mengidentifikasi, menginterpretasi, dan mereaksinya (Musfiroh dan Rahayu, 2004: 5).

Tarigan (2015: 31) mendefinisikan menyimak sebagai suatu proses kegiatan mendengarkan lambang-lambang lisan dengan penuh perhatian, pemahaman, apresiasi, serta interpretasi untuk memperoleh informasi, menangkap isi, serta memahami makna komunikasi yang hendak disampaikan oleh si pembicara melalui ujaran atau bahasa lisan. Kesadaran untuk mencapai tujuan itu menimbulkan aktivitas berpikir dalam menyimak.

Sementara itu,menurut Kamus Besar Bahasa Indonesia, menyimak: mendengarkan adalah memperhatikan baik-baik apa yang diucapkan atau dibaca orang (2005: 491).Dari beberapa pendapat di atas, dapat disimpulkan bahwa menyimak merupakan suatu proses mental bukan sekedar kegiatan mendengarkan, melainkan juga suatu proses kegiatan menangkap lambanglambang lisan dengan penuh perhatian, pemahaman, apresiasi, serta interpretasi untuk memperoleh informasi dan menghubungkannya dengan pengetahuan latar belakang yang telah dimiliki si penyimak.

Berita

Soehoet (2003: 23) menyatakan terdapat tiga definisi berita, yakni sebagai berikut.

a. Berita adalah keterangan mengenai peristiwa atau isi pernyataan manusia;

b. Berita bagi seseorang adalah keterangan mengenai peristiwa atau isi pernyataan manusia yang perlu baginya untuk mewujudkan filsafat hidupnya;

c. Berita bagi suatu surat kabar adalah adalah keterangan mengenai peristiwa atau isi pernyataan yang perlu bagi pembacanya untuk mewujudkan filsafat hidupnya.

Berita dalah informasi baru atau informasi mengenai sesuatu yang sedang terjadi, disajikan lewat bentuk cetak, siaran internet, atau dari mulut ke mulut kepada orang ketiga atau orang banyak. Berita merupakan cerita atau keterangan atau informasi mengenai kejadian atau peristiwa yang hangat. Kejadian atau peristiwa disebut hangat karena masih menjadi perhatian orang banyak atau didukung dengan penyebaran melalui media, baik cetak maupun elektronik. Menangkap isi berita, untuk menangkap isi berita, kita harus bisa mengenal pokok-pokok isi berita. Sedangkan untuk menyimak berita yang disebar luaskan melalui media elektronik baik radio, maupun televisi, diperlukan berbagai kemampuan. 


\section{Metode Team Product}

Metode Team Product merupakan metode informal pembelajaran kooperatif. Menurut Huda (2013: 130), dinamakan Team Product karena setiap kelompok diminta untuk berkreasi atau menciptakan sesuatu. Dalam metode Team Product semua hal atau kegiatan yang dilakukan oleh setiap kelompok haruslah berbentuk sebuah produk, baik itu abstrak maupun konkret. Untuk memastikan adanya tanggung jawab pada setiap peserta didik atau individu, guru dapat memberikan peran atau tugas yang berbeda-beda pada masingmasing anggota dalam setiap kelompok untuk menciptakan satu produk kelompok.

\section{METODE PENELITIAN}

\section{a. Jenis Penelitian}

Jenis penelitian yang digunakan adalah jenis penelitian deskriptif kualitatif. Sebagai penelitian kualitatif, penelitian ini didasarkan pada data alamiah berupa kata-kata dalam mendeskripsikan objek yang diteliti. Penelitian kualitatif dapat dilihat dari karakteristik penelitian yang dilakukan Bogdan \& Biklen (dalam Moleong, 2010) mengemukakan bahwa ada lima karakteristik yang melekat pada penelitian kualitatif yaitu (1) bersifat naturalistik, (2) datanya bersifat deskriptif, (3) lebih mengutamakan proses daripada hasil, (4) analisis data dilakukan secara induktif, dan (5) makna merupakan hal yang esensial dalam penelitian.

\section{b. Desain Penelitian}

Desain penelitian ini dirancang dengan penelitian tindakan sebagai salah satu bentuk penelitian kualitatif yang bertujuan untuk meningkatkan kualitas pembelajaran menulis karangan argumentasi dengan menggunakan model pembelajaran berbasis masalah. Menurut Mulyasa (2009: 88) mengatakan bahwa penelitian tindakan kelas adalah suatu cara memperbaiki dan meningkatkan profesionalisme guru, karena guru merupakan orang yang paling tahu segala sesuatu yang terjadi dalam pembelajaran. Penelitian tindakan kelas yang dilakukan secara logis dan sistematis, serta jujur dalam pelaporannya akan menjadi masukan yang sangat berharga untuk meningkatkan efisiensi dan efektivitas pembelajaran yang secara langsung akan berdampak terhadap perbaikan manajemen sekolah secara keseluruhan.

Penelitian tindakan kelas dapat dijadikan sebagai sarana penilaian pembelajaran khususnya dan pendidikan pada umumnya yang hasilnya akan memberikan masukan bermanfaat bagi pengambilan keputusan. Oleh karena itu, PTK merupakan suatu bentuk penelitian yang bersifat reflektif, melalui 
tindakan tertentu untuk memperbaiki dan meningkatkan praktik pembelajaran di kelas secara profesional.

Penelitian tindakan kelas ini bertujuan memecahkan permasalahan pembelajaran di kelas, yakni kompetensi dasar menulis karangan argumentasi. Dalam konteks pembelajaran, penelitian ini dilaksanakan sebagai upaya tindakan perbaikan terhadap kenyataan rendahnya nilai dan partisipasi siswa di dalam mengikuti pembelajaran menyimak berita.

\section{c. Data dan Sumber Data}

\section{Data penelitian}

Data penelitian ini berupa data perencanaan, data pelaksanaan, data evaluasi, dan data hasil. Data penelitian itu diperoleh melalui observasi, wawancara, dan studi dokumentasi,dan tes dari setiap tindakan perbaikan penggunaan metode team product dalam pembelajaran menyimak berita siswa Kelas VIII SMP N 4 Malunda.

\section{Sumber Data}

Data diperoleh dari subjek terteliti, yakni guru dan siswa Kelas VIII SMP N 4 Malunda yang telah mendapat intervensi pembelajaran.

\section{d. Instrumen Penelitian}

Bentuk instrumen penelitian yang berupa tes dan nontes yang digunakan untuk mengungkapkan data keterampilan menyimak dengan metode team product. Instrumen yang diberikan berupa perintah kepada peserta didik untuk melakukan kegiatan membaca ekstensif dan setelah peserta didik selesai menyimak, peserta didik langsung diperintahkan mengerjakan soal esai.

\section{Tes}

Soal pertama berkaitan dengan informasi $(5 \mathrm{~W}+1 \mathrm{H})$ dalam beberapa teks berita yang bertopik sama, sedangkan yang kedua berisi tentang masalah utama dalam beberapa teks berita yang bertopik sama. Tes dilakukan satu kali dalam tiap siklus, yaitu dilaksanakan pada akhir siklus. Jika siklus I hasilnya masih kurang atau belum sesuai dengan target yang telah ditetapkan, maka diadakan tindakan pada siklus II. Indikator Penilaian Menyimak Berita yaitu (1) Mampu menulis isi/sari berita, (2) Mampu menyimpulkan isi/sari berita, dan (3) Mampu enuliskan kembali isi/sari berita kedalam beberapa kalimat dengan susunan bervariasi.

\section{Angket}

Angket yang digunakan dalam penelitian ini adalah angket terbuka dan angket tertutup. Angket terbuka diberikan sebelum tindakan, guna mendapatkan informasi awal mengenai kendala-kendala atau permasalahan yang dihadapi peserta didik pada saat pembelajaran menyimak berita. Angket 
tertutup digunakan untuk mendapatkan informasi mengenai peningkatan kemampuan menyimak berita peserta didik. Butir pernyataan pada angket didasarkan pada kisi-kisi. Kisi-kisi tersebut disusun berdasarkan teori-teori yang digunakan dalam penelitian. Kisi-kisi angket disajikan pada lampiran nomor 1. Reliabilitas angket untuk mencapai kebenaran data dilakukan dengan menanyakan variabel yang sama baik pada pengajar maupun pada peserta didik.

Dengan demikian dapat dilihat kesesuaian antara apa yang dikatakan pengajar dengan peserta didik. Angket awal diberikan sebelum tindakan dengan 10 butir soal pilihan ganda yang semuanya harus dijawab oleh peserta didik. Angket awal ini bertujuan untuk mengetahui keadaan dalam pembelajaran menyimak berita sebelum dikenai tindakan. Sementara itu, angket akhir terdiri 13 butir soal pilihan ganda yang diberikan setelah dilakukan tindakan untuk mengetahui peningkatan kemampuan menyimak berita peserta didik dengan menggunakan metode team product.

\section{Wawancara}

Wawancara digunakan untuk memperoleh data mengenai kegiatan pembelajaran di kelas pada umumnya, kendala yang dialami guru dan peserta didik dalam kegiatan pembelajaran menyimak, serta keadaan sekolah yang membantu peneliti dalam melakukan penelitian dan identifikasi masalah. Dalam kegiatan wawancara ini digunakan instrumen lembar pertanyaan. Wawancara dilakukan sebelum tindakan dan sesudah tindakan menggunakan metode team product. Kegiatan wawancara dilakukan pada guru dan peserta didik.

\section{Lembar Pengamatan}

Pengamatan yang dilakukan dalam penelitian ini adalah pengamatan proses pembelajaran menyimak berita. Untuk menghindari subjektifitas, pengamatan dilakukan oleh observer. Lembar pengamatan digunakan untuk mencatat pelaksanaan tindakan yaitu pada saat guru menyampaikan materi pelajaran kepada peserta didik dengan menggunakan metode team product. Hal yang diamati ialah keaktifan, perhatian, gairah belajar, proses belajar, dan iklim proses belajar.

\section{e. Teknik Pengumpulan Data}

Teknik pengumpulan data dalam penelitian melalui (1) studi pendahuluan, (2) perencanaan tindakan, (3) pelaksanaan tindakan, (4) pengamatan (observasi) dan (5) refleksi. Prosedur-prosedur tersebut dilaksanakan dalam tindakan yang berdaur ulang (siklus). 


\section{f. Teknik Analisis Data}

Analisis data dilakukan berdasarkan teknik analisis data model Miles dan Huberman. Proses analisis data mengikuti langkah-langkah berikut:

\section{Tahap Menelaah Data}

Kegiatan menelaah data yang telah terkumpul berdasarkan hasil observasi , catatan lapangan, dan dokumen. Kegiatan menelaah data dilaksanakan dengan melakukan proses transkripsi hasil observasi, data nilai/hasil belajar siswa maupun hasil wawancara. Data yang telah ditranskripsikan dikelompokkan dengan masalah penelitian.

\section{Tahap Reduksi Data}

Reduksi data adalah proses penyederhanaan yang dilakukan melalui seleksi, pemfokusan, pengabtrasian data mentah menjadi informasi bermakna (Hasriati, 1995:15). Reduksi data dilakukan dengan meringkas data dalam satuan-satuan informasi sesuai dengan masalah penelitian.

\section{Tahap Penyajian Data}

Menyajikan data atau memaparkan data. Penyajian data dilakukan dengan menampilkan satuan-satuan informasi secara sistematis berdasarkan kategorinya sehingga memungkinkan peneliti menarik kesimpulan.

\section{Tahap Penyimpulan Data}

Penyimpulan data dilakukan dengan menafsirkan makna sesuatu fenomena yang terjadi selama tindakan berlangsung. Sebelum dilakukan penyimpulan akhir, terlebih dahulu dilakukan penyimpulan sementara. Penyimpulan sementara yang dilakukan peneliti diikuti dengan pengecekan keabsahan data, yaitu dengan ketekunan pengamatan, trianggulasi metode, dan pengecekan teman sejawat. Selanjutnya, peneliti menarik kesimpulan akhir setelah pengecekan keabsahan data melalui ketekunan data, trianggulasi metode, dan pengecekan teman sejawat mendukung kesimpulan sementara.

\section{HASIL DAN PEMBAHASAN}

Pembahasan hasil penelitian meliputi hasil tes dan nontes. Setelah dilaksanakan analisis data tes dan nontes, diperoleh hasil bahwa penerapan metode team product dapat meningkatkan kemampuan menyimak berita pada peserta didik kelas VIII $_{\text {D }}$ SMP Negeri 4 Malunda. Pembahasan hasil penelitian meliputi pembelajaran kemampuan menyimak berita, peningkatan kemampuan menyimak berita, dan perubahan tingkah laku peserta didik setelah dilakukan kemampuan menyimak berita satu babak melalui metode team product.

Pembahasan pembelajaran mencakup segala aktivitas di kelas ketika kemampuan menyimak berita satu babak melalui metode team product. 
Peningkatan kemampuan menyimak berita peserta didik dapat dilihat dari hasil tes siklus I dan siklus II, sedangkan perubahan tingkah laku peserta didik setelah dilakukan kemampuan menyimak berita satu babak melalui metode team product dapat dilihat dari hasil nontes siklus I dan siklus II.

Kemampuan menyimak berita melalui metode team product dilakukan dalam dua siklus, yaitu siklus I dan siklus II. Siklus II dilaksanakan apabila pada siklus I terdapat beberapa kekurangan yang dapat diketahui dari hasil tes dan nontes. Dari hasil tes dan nontes tersebut, kemudian dapat disimpulkan kegiatan apa saja yang harus dilakukan untuk memperbaiki pembelajaran pada siklus selanjutnya. Peneliti menggunakan metode team product di kelas $\mathrm{VIII}_{\mathrm{D}}$ SMP Negeri 4 Malunda Kabupaten Majene.

\section{SIMPULAN}

Berdasarkan deskripsi hasil penelitian dan pembahasan yang telah diuraikan pada bab sebelumnya maka dapat disimpulkan bahwa pelaksanaan pembelajaran menyimak berita dengan menggunakan metode team product pada peserta didik kelas VII SMPN 3 Malunda berjalan dengan lancar. Dari segi produk, terjadi peningkatan kemampuan menyimak berita pada peserta didik dengan meningkatnya jumlah peserta didik pada masing-masing indikator keberhasilan dari pratindakan hingga siklus kedua, seperti peserta didik mampu menuliskan kembali isi/sari berita ke dalam beberapa kalimat dengan susunan bervariasi. Sementara itu, dari segi proses kendala-kendala yang dialami peserta didik seperti pelannya suara pembacaan berita dan kendala yang dialami guru seperti sulitnya peserta didik konsentrasi sudah bisa diatasi melalui penerapan metode team product. bertanya, berani mengeluarkan pendapat, berani menjawab pertanyaan, serta terlihat lebih aktif dan antusias dalam menyimak berita.

\section{SARAN DAN REKOMENDASI}

Berdasarkan hasil kesimpulan penelitian dapat diajukan saran sebagai berikut.

1. Bagi Guru

Strategi pembelajaran aktif team product yang digunakan dalam penelitian ini dapat memberikan masukan bagi guru mata pelajaran Bahasa Indonesia sebagai salah satu strategi alternatif dalam pembelajaran menyimak berita atau pembelajaran dengan keterampilan lainnya.

2. Bagi Peserta didik 
Peserta didik harus lebih aktif dan antusias dalam mengikuti pembelajaran dengan menggunakan metode team product atau strategi pembelajaran aktif lainnya.

3. Bagi Sekolah

Pihak sekolah harus lebih memperhatikan dan memantau kegiatan pembelajaran di kelas agar kualitas tenaga pendidik dan peserta didik menjadi lebih baik.

\section{DAFTAR PUSTAKA}

Budiman, Kris. 2012. Dasar-dasar Jurnalistik.http://www.akirahmedia.com. Diunduh pada tanggal 24 April 2016.

Forehand, Mary. 2012. Bloom's Taxonomy. http://projects.coe.uga.edu/ . Diunduh pada Tanggal 12 April 2016.

Haryanto, dkk. 2008. Seribu Peta Bahasa Indonesia untuk SMP/ MTs Kelas VIII. Jakarta: Erlangga.

Haryanto. 2012. Keterlibatan Peserta didik dalam Belajar Mengajar. http://belajarpsikologi.com. Diunduh pada tanggal 12 April 2016.

Hidayah, Aprilia Kartika. 2010. Keefektifan Metode Snowball Throwing terhadap Kemampuan Menyimak Berita Peserta didik Kelas VIII SMPN 5 Depok Sleman. Skripsi SI. Yogyakarta: Program Studi Pendidikan Bahasa dan Sastra Indonesia, FBS UNY.

Huda, Miftahul. 2015. Cooperative Learning. Pustaka Pelajar: Yogyakarta.

Musfiroh, Tadkiroatun \& Rahayu, Dwi Hanti. 2004. Menyimak Komprehensif dan Kritis. Yogyakarta: UNY.

Nurgiyantoro, Burhan. 2001. Penilaian dalam Pengajaran Bahasa dan Sastra. Yogyakarta: BPFE.

Nurgiyantoro, Burhan. 2010. Penilaian Pembelajaran Bahasa Berbasis Kompetensi. Yogyakarta: BPFE.

Prasetya, Budi. 2013. Jenis Menyimak. http://budicrue.multiply.com. Diunduh pada tanggal 08 Januari 2013.

Silberman, Melvin. 2012. Active Learning (101 Cara Peserta didik Belajar Aktif). Nuansa: Bandung.

Soehoet, Haoeta. 2003. Dasar-dasar Jurnalistik. Yayasan Kampus TercintaIISIP:Jakarta.

Sudijono, Anas. 2008. Pengantar Evaluasi Pendidikan. PT Raja Grafindo Persada: Jakarta. 
Suharsono \& Retnoningsih, Ana. 2005. Kamus Besar Bahasa Indonesia. Semarang: Widya Karya.

Tarigan, Henry Guntur. 2008. Keterampilan Berbahasa. Bandung: Angkasa.

Tarigan, Henry Guntur. 2015. Menyimak sebagai Suatu Keterampilan Berbahasa. Bandung: Angkasa.

Thohiron, Dion. 2013. Hakekat Menyimak. http://id.shvoong.com. Dinduh pada tanggal 08 Januari 2013.

Wiriaatmadja, Rochiati. 2007. Metode Penelitian Tindakan Kelas. Bandung: PT Remaja Rosdakarya.

Zaini, Hisyam dkk. 2011. Strategi Pembelajaran Aktif. Yogyakarta: CTSD. 